\title{
KIITTR

\section{INTERNALISASI KARAKTER KEMANDIRIAN PADA MATA PELAJARAN PAI (Kajian Atas Proses Pembelajaran di SMP N 2 BABAT Lamongan)}

\author{
Salman Zaihidi \\ Universitas Islam Lamongan \\ salmanzahidi04@gmail.com
}

\section{Article History:}

Received : 09-07-2019

Revised : 20-08-2019

Accepted : 05-09-2019
Abstract: One of the mandates of education is to form a superior personality, one of which is shown by the character of independence inherent in students as a result of the educational process. Thus, it is essential to research the internalization of the character of autonomy through the learning process of Islamic religious education. Research using this qualitative method aims to determine the implementation of Islamic Education learning and internalizing values. The study found, among others: 1) In the process of internalizing the teacher plays a significant role as a transmitter of values in the Islamic Education learning process; 2) The character of independence can be internalized properly, one of which is through the habituation method used by the teacher to students when Islamic Islamic Education learning takes place; 3) The actualization of the students' independence character values varies, either during the learning process or outside of school. This indicates that the internalization of values runs quite well through daily life and students' views of the values associated with the formation of an independent personality, such as having a learning ethos, selfconfidence, and creativity.

Keyword : Internalitation, independent character, PAI

\section{Pendahuluan}

Pendidikan sampai saat ini masih dipercaya sebagi media yang dapat digunakan dalam membangun kecerdasan sekaligus membentuk sikap anak untuk menjadi lebih baik. Oleh karena itu, pendidikan secara terus menerus harus dibangun dan dikembangkan dalam proses pelaksanaanya agar menghasilkan generasi yang diharapkan. Pendidikan merupakan usaha yang dilakukan secara sadar dan terencana untuk mewujudkan suasana balajar dan proses pembelajaran agar peserta didik secara aktif mengembangkan kemampuan keagamaan, pengendalian diri, kepribadian, kecerdasan, akhlak mulia, serta ketrampilan yang diperlukan dirinya, masyarakat, bangsa dan negara. ${ }^{1}$

1 Depdiknas,Undang-Undang No. 20 Tahun 2003:Tentang Sistem Pendidikan Nasional (Jakarta: t.p., 2003), 3. 
Menurut Undang-Undang Nasional No. 20 Tahun 2003 pasal 3 menjelaskan bahwa tujuan dari pendidikan nasional adalah "untuk mengembangkan kemampuan peserta didik agar menjadi manusia yang beriman dan bertaqwa kepada Tuhan Yang Maha Esa, berakhlak mulia, sehat, berilmu, cakap, kreatif, mandiri, dan menjadi warga negara yang demokratis serta tanggung jawab". ${ }^{2}$

Dari uraian di atas menjelaskan tentang pentingnya karakter yang harus diinternalisasikan dalam diri anak, maka diperlukan pendidikan karakter yang dilakukan dengan tepat, sehingga setelah menerima pendidikan karakter anak memiliki nilai-nilai perilaku yang baik. Baik itu perilaku anak yang berhubungan dengan Tuhan Yang Maha Esa, sesama manusia, dan lingkungan.

Internalisasi merupakan proses penanaman dan menumbuh kembangkan suatu nilai atau budaya melalui suatu penghayatan, pendalaman penguasaan secara mendalam yang berlangsung melalui binaan dan bimbingan agar menjadi individu yang memiliki karakter. $^{3}$

Setelah peneliti melakukan pengamatan di SMP N 2 Babat Lamongan bahwa masih terdapat siswa yang kurang memiliki karakter kemandirian dalam dirinya. Seperti, pada saat pembelajaran Pendidikan Agama Islam berlangsung siswa diberi tugas oleh guru untuk mempelajari bab selanjutnya tetapi masih terdapat siswa yang tidak mempelajari materi tersebut, masih terdapat siswa yang bergantung pada pimikiran teman, minimnya siswa untuk berani mengemukakan pendapat atau bertanya selama pembelajaran berlangsung, terdapat siswa yang keluar kelas saat menunggu pergantian pelajaran atau terlambat masuk kelas, terdapat siswa yang telat mengumpulkan tugas yang diberikan guru. ${ }^{4}$

Dalam hal ini peran sekolah sebagai tempat pendidikan nilai dan karakter tidak dapat dihindarkan lagi. Oleh karena itu, pada tahun 2016 Kementrian Pendidikan dan Kebudayaan (Kemendikbud) mensosialisasikan lima nilai karakter utama yang bersumber dari Pancasila dalam Gerakan Penguatan Pendidikan Karakter (PPK). ${ }^{5}$ Salah satu nilai karakter utama tersebut adalah mandiri.

Mandiri menunjukkan sikap dan perilaku individu atas dasar inisiatif dan kemampuan sendiri. Sehingga nilai-nilai karakter mandiri sangat penting dimiliki oleh siswa karena pada hakikatnya nilai karakter mandiri sangat berkaitan dengan diri pribadi manusia. Nilai karakter mandiri dapat menjadi awal dari pengembangan nilai-

${ }^{2}$ Ibid., 5.

${ }^{3}$ Novia Irma Lutviyanti, "Internalisasi Pendidikan Karakter Dalam Membentuk Kemandirian Anak Di Pondok Asih Sesami Kecamatan Baturetno Kapupaten Wonogiri", Jurnal Ilmiah Pend. Sos Ant, Vol. 3, No. 2 (2013), 4 .

${ }^{4}$ SMP N2 Babat Lamongan, Observasi, Babat, 20 November 2019.

5 Nilai-nilai Penguatan Pendidikan Karakter (PPK) ada 5 yaitu: Rerigius, Nasional, Integritas, Gotong Royong, dan Mandiri. 
nilai karakter yang lainnya. Oleh karena itu, nilai karakter mandiri harus dapat diinternalisasikan dengan baik dalam diri siswa. ${ }^{6}$

Salah satu alternatif yang dapat dilakukan dalam melaksanakan pendidikan karakter di sekolah adalah dengan cara mengoptimalkan pembelajaran materi Pendidikan Agama Islam (PAI). Karena di dalam pendidikan agama Islam terdapat sarana untuk mentransformasi pengetahuan dalam keagamaan (aspek kognitif), sebagai sarana transformasi norma serta nilai moral untuk membentuk sikap (aspek afektif), dan berperan dalam mengendalikan prilaku (aspek psikomotorik) sehingga tercipta kepribadian manusia seutuhnya. ${ }^{7}$

SMP N 2 Babat Lamongan merupakan salah satu lembaga pendidikan yang berada di kecamatan Babat yang ditunjuk Dinas Pendidikan untuk menerapkan nilainilai Penguatan Pendidikan Karakter (PPK) sejak pada tahun 2017. ${ }^{8}$

Dalam menanamkan dan mengembangkan nilai karakter kemandirian, guru PAI SMP N 2 Babat Lamongan menggunakan cara membiasakan siswa untuk mengerjakan tugas secara mandiri, datang tepat waktu, dan melaksanakan salat berjamaah. Sehingga melalui pembiasaan tersebut, siswa diharapkan mampunyai nilai karakter kemandirian, seperti mempunyai sikap disiplin, baik itu disiplin dari segi belajarnya, tingkah lakunya, cara bicaranya, dan juga melatih anak untuk mempunyai rasa tanggung jawab. ${ }^{9}$

Permasalahan yang berhubungan dengan kemandirian di era globalisasi sekarang ini masih sering ditemui di lingkungan sekitar, termasuk di lingkungan pendidikan.10 Seperti, kurangnya kemandirian pada diri siswa akan mengakibatkan siswa tersebut memiliki kecenderungan untuk bergantung pada orang lain, kurangnya kreativitas, malas, kurang percaya diri dan tidak dapat memecahkan masalahnya sendiri.

Berdasarkan fenomena-fenomena di atas penulis mencoba mendefinisikan tentang bagaimana proses pembelajaran karakter kemandirian dalam mata pelajaran Pendidikan Agama Islam di SMP N 2 Babat Lamongan, bagaimana proses pembiasaan karakter kemandirian dalam mata pelajaran Pendidikan Agama Islam di SMP N 2 Babat Lamongan, dan bagaimana aktualisasi karakter kemandirian dalam mata pelajaran Pendidikan Agama Islam di SMP N 2 Babat Lamongan.

Penelitian ini menggunakan metode kualitatif dengan pendekatan fenomenologi. Sedangkan untuk melakukan analisis data, dilakukan setelah melakukan proses mencari dan menyusun secara sistematis data yang diperoleh dari hasil wawancara, catatan

6 Ulfa Khoirotul Rosidah, "Pelaksanaan Pendidikan Karakter Mandiri dalam Kegiatan Ekstrakurikuler Panahan di SDN Puro Pakualaman I Yogyakarta”, Jurnal Pendidikan Guru Sekolah Dasar Edisi 28 Tahun ke-7 2018.

${ }^{7}$ Nur Ainiyah, "Pembentukan Karakter melalui Pendidikan Agama Islam”, Jurnal Al-Ulum Vol. 13, No.1,( Juni, 2013), 26.

${ }^{8}$ Kholifatul Maghfuroh, Wawancara, Babat, 20 November 2019.

${ }^{9}$ Ibid,.

10Ulfa Khoirotul Rosidah, "Pelaksanaan Pendidikan Karakter Mandiri dalam Kegiatan Ekstrakurikuler Panahan di SDN Puro Pakualaman I Yogyakarta”, 2. 
lapangan, dan dokumentasi, dengan cara mengelompokkan data sampai membuat kesimpulan. ${ }^{11}$

\section{Diskursus Internalisasi Nilai Kemandirian}

Menurut kamus besar bahasa Indonesia Internalisasi diartikan sebagai penghayatan, penugasan, penguasaan secara mendalam yang berlangsung melalui pembinaan, bimbingan, penyuluhan, penataran, dan sebagainya. Sedangkan dalam pengertian psikologis, internalisasi mempunyai arti penyatuan sikap atau penggabungan, standart tingkah laku, pendapat, dalam kepribadian. ${ }^{12}$

Menurut Thomas Lickona yang dikutip oleh Dharma Khesuma, bahwa proses internalisasi antara lain: ${ }^{13}$ 1. Pengetahuan Moral (moral knowing), memiliki enam ranah yaitu: Kesadaran moral, Pengetahuan nilai moral, Memahami Sudut Pandang lain, Penalaran moral, Pembuatan putusan, dan Pengetahuan diri. 2. Perasaan Moral (moral feeling), memiliki enam ranah yaitu: Hati nurani, Harga diri, Empati, Cinta kebaikan, Kontrol diri, dan Rendah hati. 3. Tindakan Moral (moral action), memiliki tiga ranah yaitu: Kompetensi moral, Keinginan moral, dan Kebiasaan.

Hakikat pembelajaran secara umum dilukiskan oleh Gagne dan Briggs, adalah serangkaian kegiatan yang dirancang yang memungkinkan terjadinya proses belajar. Pembelajaran mengandung makna setiap kegiatan untuk membantu individu mempelajari kecakapan tertentu. ${ }^{14}$

Menurut Mulyasa pembiasaan adalah sesuatu yang dilakukan secara berulangulang agar sesuatu itu menjadi kebiasaan. Pembiasaan sebenarnya berawal dari pengalaman, yang dibiasakan itu merupakan sesuatu yang diamalkan. ${ }^{15}$

Sedangkan aktualisasi dapat diartikan sebagai kemampuan dalam menggabungkan dan menyatukan sikap, standar tingkah laku dan pendapat di dalam kepribadian. ${ }^{16}$

\section{Karakter Kemandirian: Pengertian dan Ciri-Cirinya}

Karakter secara bahasa adalah watak, tabiat, akhlak, atau kepribadian seseorang yang terbentuk dari hasil internalisasi sebagai kebijakan (virtues) yang diyakini dan

11 Sugiono, Metode Penelitian Kuantitatif, Kualitatif, dan R\&D (Bandung: Alfabeta, t.t), 244.

12 Muhamad Mahmud, "Internalisasi Nilai-nilai Karakter dalam Meingkatkan Kompetensi Kepibadian Guru di Sekolah Menengah Pertama Islam Terpadu (SMPIT) Al-Hidayah Sumenep" (TesisUniversitas Islam Negeri Maulana Malik Ibrahim Malang, 2017), 47.

13 Dharma Kesuma, dkk, Pendidikan Karakter: Kajian Teori dan Praktik Sekolah (Bandung: PT Remaja Rosdakarya, 2018), 70.

14 Karwono dan Heni Mularsih, Belajar dan Pembelajaran Serta Pemanfaatan Sumber Belajar (Depok: PT Raja Grafindo Persada, 2018), 19-20.

15 Mulyasa, Manajemen Pendidikan Karakter (Jakarta: PT Bumi Aksara, 2018), 166.

16 Annisa Mayasari, " Implementasi Pendidikan Karakter dan Aktualisasi Nilai-Nilai Religius-Sosial dalam Sistem Boarding School Di SMA Islam Terpadu Abu Bakar Yogyakarta” (Skripsi--UIN Sunan Kalijaga Yogyakarta, 2018), 21. 
digunakan sebagai landasan cara pandang, berfikir, bersikap dan bertindak. ${ }^{17}$ Sedangkan kemandirian adalah kemapuan untuk mengelola semua yang dimilikinya sendiri yaitu mengetahui bagaimana mengelola waktu, berjalan dan berpikir secara mandiri dan menggunakan kemampuannya dalam mengambil keputusan dan memecahkan masalah. ${ }^{18}$

Jadi dari uraian di atas dapat disimpulkan bahwa karakter kemandirian adalah suatu sifat atau tingkah laku yang melekat pada diri seseorang, yang mencerminkan suatu keadaan dimana orang tersebut mampu berdiri sendiri tanpa bantuan dari orang lain.

Nilai-nilai karakter mandiri antara lain: ${ }^{19}$

a. Etos kerja (kerja keras) merupakan suatu sikap dan kebiasaan kerja yang terdapat dalam diri seseorang dengan standar tertentu untuk bisa mencapai suatu hasil yang maksimal.

b. Berdaya juang adalah suatu kemampuan dalam menghadapi dan bertahan terhadap kesulitan hidup sebagai suatu proses dalam mengembangkan diri dan mencapai tujuan.

c. Kreatif merupakan suatu kemampuan untuk menciptakan hal-hal baru baik itu berupa ide atau kenyataan yang berbeda dengan apa yang sudah ada sebelumnya.

d. Keberanian adalah suatu sikap yang mana mempunyai hati yang mantap dan percaya diri yang tinggi dalam dalam menghadapi bahaya, kesulitan

e. Pembelajar sepanjang hayat berarti konsep tentang belajar secara terus menerus, saling berkesinambungan, dan sejalan dengan fase perkembangan pada manusia.

Menurut Chabib Thoha, ciri-ciri kemandirian belajar dibagi dalam tujuh jenis, yaitu: Mampu berpikir secara kritis, kreatif dan inovatif, tidak mudah terpengaruh oleh pendapat orang lain, tidak lari atau menghindari masalah, memecahkan masalah dengan berpikir mendalam, apabila menjumpai masalah dipecahkan sendiri tanpa meminta bantuan, berusaha bekerja dengan penuh ketekunan dan kedisiplinan, dan bertanggung jawab atas tindakannya sendiri.20

Faktor-faktor yang mempengaruhi kemandirian antara lain: 1. Faktor internal merupakan faktor yang berasal dari dalam diri anak, antara lain: gen atau keturunan orang tua, ${ }^{21}$ jenis kelamin, urutan posisi anak, ${ }^{22}$ dan kecerdasan ${ }^{23}$. 2. Faktor eksternal

${ }^{17}$ Anas salahudin dan Irwanto Alkrienciehie, Pendidikan Karakter: Pendidikan berbasis Agama dan Budaya Bangsa (Bandung: CV. Pustaka Setia, 2013) ,44.

${ }^{18}$ Toni Nasution, "Membangun Kemandirian Siswa Melalui Pendidikan Karakter", Jurnal Ijtimaiyah, Vol. 2, No. 1, (Januari-Juni, 2018),3.

${ }^{19}$ Lestari Neng Purwanti, Penguatan Pendidikan Karakter (PPK) (Jakarta Timur: Penerbit Erlangga, 2018), 135-136.

${ }^{20}$ Rianawati, "Internalisasi Karakter Kemandirian Melalui Pembelajaran Konstruktif di Perguruan Tinggi”, Jurnal At-Turats, Vol. 8, No.2, (1 Desember, 2014), 10.

21 Ibnu Kholid Hidayat, "Upaya Guru Dalam Membentuk Kemandirian Siswa (Studi Kasus di SD Negeri Bulupayung 02)", (Skripsi-Institut Agama Islam Negeri (IAIN) Purwokerto, 2017), 28.

${ }^{22}$ Toni Nasution, "Membangun Kemandirian Siswa Melalui Pendidikan Karakter", 8. 
merupakan faktor yang berasal dari luar dirinya, atau sering disebut dengan faktor lingkungan antara lain: pola asuh orang tua, ${ }^{24}$ sistem pendidikan di sekolah, ${ }^{25}$ dan sistem kehidupan di masyarakat ${ }^{26}$.

\section{Pendidikan Agama Islam}

Menurut Baharuddin Pendidikan Agama Islam merupakan suatu upaya atau proses, pencarian, pembentukan, dan pengembangan sikap atau prilaku untuk mencari, memelihara serta menggunakan ilmu-ilmu dan ketrampilan untuk kepentingan manusia sesuai dengan ajaran Islam. ${ }^{27}$

Tujuan dari Pendidikan Agama Islam adalah untuk meningkatkan pengetahuan dan pemahaman tentang ajaran Islam, meningkatkan ketrampilan dalam prakteknya, dan meningkatkan pengamalan ajaran Islam dalam kehidupan sehari-harinya.

Ruang lingkup Pendidikan Agama Islam, antara lain: 1. Materi akidah dan akhlak adalah materi yang mengutamakan penanaman keyakinan iman yang dilandasi dengan tauhid yang terefleksi dalam keseluran baik itu sikap, tindakan, dan perilaku manusia. 2 . Materi ibadah merupakan wujud ketaatan manusia kepada Allah dengan cara menjalankan kewajiban-Nya. 3. Materi sejarah Islam adalah materi yang berfungsi untuk menanamkan semangat juang untuk mewujudkan kebenaran dengan belajar dari para sahabat Rasul dan tokoh yang menjadi role model dalam perjalanan sejarah Islam. ${ }^{28}$

\section{Proses Pembelajaran PAI di SMPN 2 Babat}

Dalam rangka menginternalisasikan karakter kemandirian dalam proses pembelajaran Pendidikan Agama Islam guru di SMP N 2 Babat Lamongan telah melakukan serangkaian kegiatan yang dirancang agar nilai karakter kemandirian masuk dalam proses pembelajaran. Menurut Gagne dan Briggs yang dikutip oleh Karwono dkk bahwa pembelajaran merupakan serangkaian kegiatan yang dirancang yang memungkinkan terjadinya proses belajar. ${ }^{29}$ Di SMP N 2 Babat Lamongan guru PAI sebelum melaksanakan pembelajaran telah membuat Rencana Pelaksanaan Pembelajaran (RPP) terlebih dahulu.

23 Rika sa'diyah, "Pentingnya Melatih Kemandirian Anak", Jurnal Kordinat, Vol. 16, no.1 (April, 2017), 40.

24 Ibid., 7.

${ }^{25}$ Rianawati, "Internalisasi Karakter Kemandirian Melalui Pembelajaran Konstruktif di Perguruan Tinggi", 11.

26Ibnu Kholid Hidayat, "Upaya Guru Dalam Membentuk Kemandirian Siswa (Studi Kasus di SD Negeri Bulupayung 02)", 29.

27 Baharuddin, Pendidikan dan Psikologi Perkembangan (Jogjakarta: Ar-Ruzz Media, 2017), 197.

28 T.p, Pendidikan Islam: Memajukan Umat dan Memperkuat Kesadaran Bela Negara (Jakarta: Kencana, 2016), 13-14.

${ }^{29}$ Karwono dan Heni Mularsih, Belajar dan Pembelajaran Serta Pemenfaatan Sumber Belajar, 19. 
Menurut Toto Ruhimat dalam proses pembelajaran terdapat tiga tahapan prosedur pembelajaran, sebagai berikut: kegiatan awal pembelajaran, kegiatan inti pembelajaran, dan kegiatan akhir pembelajaran. ${ }^{30}$

1. Kegiatan Awal Pembelajaran

Kegiatan awal pembelajaran harus dapat menciptakan awal pembelajaran yang efektif yang memungkinkan siswa dapat mengikuti proses pembelajaran dengan baik. Berdasarkan pengamatan atau observasi di kelas pada saat pembelajaran PAI berlangsung, dan wawancara. Guru PAI menginternalisasikan nilai karakter kemandirian melalui kegiatan awal pembelajaran dengan cara: guru memeriksa kebersihan kelas terlebih dahulu (nilai daya juang dan pemberani), memeriksa kerapian berpakaian (nilai daya juang), mengabsen siswa (nilai daya juang), menyetorkan hafalan yang sudah menjadi tugas minggu kemarin (nilai karakter kerja keras), serta mereview materi minggu kemarin (nilai karakter daya juang).

2. Kegiatan Inti Pembelajaran

Pada kegiatan inti pembelajaran akan menekan pada proses pembentukan pengalaman belajar siswa dalam materi pelajaran yang sudah disusun dan direncanakan oleh guru. Di SMP N 2 Babat Lamongan dalam kegiatan inti ini guru menggunakan metode pembelajaran Inkuiri dan cooperative learning yang mana dengan menggunakan metode tersebut akan mengajarkan siswa tentang nilai karakter kemandirian dengan mengajak siswa untuk menyelesaikan tugas secara berkelompok, yang didalamnya akan mengajarkan nilai karakter kemandirian antara lain: kerja keras, kreatif, daya juang, pemberani, dan pembelajar.

3. Kegiatan Akhir Pembelajaran

Kegiatan akhir dalam pembelajaran tidak hanya diartikan sebagai kegiatan menutup pelajaran yang dilakukan oleh guru, melainkan juga sebagai kegiatan penilaian hasil belajar siswa serta kegiatan tindak lanjut. Di SMP N 2 Babat Lamongan guru PAI menginternalisasikan nilai karakter kemandirian pada kegiatan akhir pembelajaran dengan cara: guru mengajak siswa secara bersaama menyimpulkan materi pelajaran (nilai karakter pemberani, dan kreatif), memberikan tugas untuk mengerjakan latihan akhir bab yang dikumpulkan minggu depan (nilai karakter pembelajar, kerja keras, dan daya juang), dan memberi tugas untuk mempelajari bab yang akan dibahas pada pertemuan selanjutnya (nilai karakter pembelajar).

30 Toto Ruhimat, Prosedur Pembelajaran, t.t, 1. 


\section{Proses Pembiasaan Karakter Kemandirian dalam Mata Pelajaran Pendidikan Agama Islam di SMP N 2 Babat Lamongan}

Dalam menginternalisasikan nilai karakter kemandirian dalam proses pembiasaan dalam mata pelajaran Pendidikan Agama Islam guru PAI di SMP N 2 Babat Lamongan melakukan pembiasaan karakter kemandirian kepada siswa secara berulangulang agar melekat pada diri siswa, sehingga menjadi suatu kebiasaan. Menurut Mulyasa pembiasaan dalam pendidikan dapat dilaksanakaan secara terprogram dalam pembelajaran dan secara tidak terprogram dalam kegiatan sehari-hari. ${ }^{31}$

1. Kegiatan secara terprogram dalam pembelajaran

Kegiatan pembiasaan nilai karakter kemandirian yang dilakukan guru dalam pembelajaran Pendidikan Agama Islam tentunya mempunyai tujuan untuk mengembangkan pribadi peserta didik baik secara individu atau kelompok. Guru PAI di SMP N 2 Babat Lamongan membiasakan nilai karakter kemandirian kepada siswa dalam pembelajaran melalui berbagai cara antara lain: pertama guru memberikan sebuah motivasi atau memberikan respon kepada siswa agar berani untuk mengemukakan pendapat, melalui kegiatan tersebut siswa terbiasa melaksanakan nilai karakter kreatif. Kedua guru membiasakan siswa untuk menghafalkan surat-surat pendek, menanamkan pada diri siswa untuk mengerjakan tugas sesuai dengan kemampuan, serta pada saat waktu ulangan harian menggunakan ujian secara lisan merupakan cara yang digunakan guru untuk membiasakan siswa melaksanakan nilai karakter kerja keras. Ketiga guru memberikan tugas kepada siswa untuk belajar mandiri seperti mambaca, mengerjakan soal latihan, merangkum materi dan berdiskusi dengan temannya. Melalui kegiatan tersebut siswa terbiasa melaksanakan nilai karakter pembelajar. Keempat guru memberikan motivasi dan memberikan suatu kepercayaan kepada siswa, dengan cara ini guru akan membiasakan nilai karakter pemberani kepada siswa.

2. Kegiatan secara tidak terprogram dalam kegiatan sehari-hari

Selain membiasakan siswa melalui kegiatan terprogram dalam proses pembelajaran, pembiasaan nilai karakter kemandirian dapat dilakukan secara tidak terprogram dalam kegiatan sehari-hari di lingkungan sekolah. Guru PAI di SMP N 2 Babat Lamongan juga melakukan kegiatan pembiasaan di luar jam pembelajaran PAI, pembiasaan tersebut juga berkaiatan dengan pelajaran PAI, seperti membiasakan siswa untuk melakukan 5 S (salam, sapa, senyum, sopan, dan santun) kepada guru dan karyawan di sekolah. Serta setiap pagi membiasakan siswa untuk berjabat tangan dengan guru (salam ta'dim). Melalui kegiatan pembiasaan tersebut, diharapkan siswa memiliki nilai karakter daya juang.

31 Mulyasa, manajemen pendidikan karakter , 167. 


\section{Aktualisasi Karakter Kemandirian dalam Mata Pelajaran Pendidikan Agama Islam} di SMP N 2 Babat Lamongan

Aktualisasi nilai karakter kemandirian merupakan kemampuan dalam menggabungkan dan menyatukan sikap, standar tingkah laku, dan pendapat dalam kepribadian. ${ }^{32}$ Dalam proses aktualisasi nilai karakter kemandirian guru PAI di SMP N 2 Babat Lamongan membutuhkan waktu yang cukup panjang dan harus dilakukan secara konsisten dan terus menerus untuk mengambangkan kemampuan dan menyesuaikan diri siswa dengan lingkungan sekitar.

Aktualisasi nilai karakter kemandirian siswa dapat diketahui melalui kebiasaan siswa pada saat pembelajaran berlangsung, wawancara dengan teman sebaya serta dilihat dari karakter siswa di luar jam pembelajaran. Seperti siswa berani menegur temannya yang menyontek, tetapi tidak semua siswa berani untuk menegur teman yang menyontek. Sikap aktif dalam kegiatan berdiskusi kelompok. Mengisi waktu luang untuk membaca atau mengerjakan tugas, tetapi tidak semua siswa dapat menerapkan sikap tersebut. Sikap berani mengemukakan pendapatnya baik pada saat guru menerangkan atau pada saat berdiskusi serta melaksanakan salat berjamaah.

\section{Kesimpulan}

Berdasarkan hasil pembahasan, berkaitan dengan Internalisasi Karakter Kemandrian dalam Mata Pelajaran Pendidikan Agama Islam di SMP N 2 Babat Lamongan, dapat ditarik kesimpulan sebagai berikut: 1) Proses pembelajaran karakter kemandirian, guru PAI telah menginternalisasikan nilai karakter kemandirian dalam proses pembelajaran PAI, 2) Proses pembiasaan nilai karakter kemandirian, guru PAI menginternalisasikan melalui kegiatan terprogram yaitu kegiatan pembelajaran dan kegiatan tidak terprogram dalam kegiatan sehari-hari siswa di lingkungan sekolah, 3) Aktualisasi nilai karakter kemandirian, siswa telah mengimplementasikan secara bervariasi, namun sudah banyak siswa yang menerapkan nilai karakter kemandirian hanya saja sebagian siswa yang belum menerapkan nilai karakter kemandirian.

\section{DAFTAR PUSTAKA}

Ainiyah, Nur. "Pembentukan Karakter melalui Pendidikan Agama Islam". Jurnal Al-Ulum Vol. 13, No.1,Juni, 2013.

Baharuddin, Pendidikan dan Psikologi Perkembangan. Jogjakarta: Ar-Ruzz Media, 2017. Hidayat, Ibnu Kholid. "Upaya Guru Dalam Membentuk Kemandirian Siswa (Studi Kasus di SD Negeri Bulupayung 02)". Skripsi-Institut Agama Islam Negeri (IAIN) Purwokerto, 2017.

Karwono dan Heni Mularsih. Belajar dan Pembelajaran Serta Pemenfaatan Sumber Belajar. Depok: PT Raja Grafindo Persada, 2018.

32 Annisa Mayasari, "Implementasi Pendidikan Karakter dan Aktualisasi Nilai-Nilai Religius-Sosial dalam System Boarding School di SMA Islam Terpadu Abu Bakar Yogykarta, 21. 
Kesuma, Dharma.dkk, Pendidikan Karakter: Kajian Teori dan Praktik Sekolah.Bandung: PT Remaja Rosdakarya, 2018.

Lutviyanti, Novia Irma. "Internalisasi Pendidikan Karakter Dalam Membentuk Kemandirian Anak Di Pondok Asih Sesami Kecamatan Baturetno Kapupaten Wonogiri". Jurnal Ilmiah Pend. Sos Ant, Vol. 3, No. 2, 2013.

Mahmud, Muhamad. "Internalisasi Nilai-nilai Karakter dalam Meingkatkan Kompetensi Kepibadian Guru di Sekolah Menengah Pertama Islam Terpadu (SMPIT) AlHidayah Sumenep". Tesis-Universitas Islam Negeri Maulana Malik Ibrahim Malang, 2017.

Mayasari, Annisa. "Implementasi Pendidikan Karakter dan Aktualisasi Nilai-Nilai Religius-Sosial dalam System Boarding School di SMA Islam Terpadu Abu Bakar Yogykrta". Skripsi-UIN Sunan Kalijaga Yogyakarta, 2018.

Mulyasa. manajemen pendidikan karakter. Jakarta: PT Bumi Aksara, 2018.

Nasution, Toni. "Membangun Kemandirian Siswa Melalui Pendidikan Karakter". Jurnal Ijtimaiyah, Vol.2, No.1, Januari-Juni, 2018.

Purwanti, Lestari Neng. Penguatan Pendidikan Karakter (PPK). Jakarta Timur: Penerbit Erlangga, 2018.

Rianawati. "Internalisasi Karakter Kemandirian Melalui Pembelajaran Konstruktif di Perguruan Tinggi", Jurnal At-Turats, Vol. 8, No. 2, Desember, 2014.

Rosidah, Ulfa Khoirotul. "Pelaksanaan Pendidikan Karakter Mandiri dalam Kegiatan Ekstrakurikuler Panahan di SDN Puro Pakualaman I Yogyakarta". Jurnal Pendidikan Guru Sekolah Dasar Edisi 28 Tahun ke-7 2018.

Ruhimat, Toto. Prosedur Pembelajaran. t.t.

Sa'diyah, Rika. "Pentingnya Melatih Kemandirian Anak", Jurnal Kordinat, Vol. 16 No. 1, April, 2017.

Salahudin, Anas dan Irwanto Alkrienciehie, Pendidikan Karakter: Pendidikan berbasis Agama dan Budaya Bangsa. Bandung: CV. Pustaka Setia, 2013.

Sugiono. Metode Penelitian Kuantitatif, Kualitatif, dan R\&D. Bandung: Alfabeta, t.t.

T.p. Pendidikan Islam: Memajukan Umat dan Memperkuat Kesadaran Bela Negara. Jakarta: Kencana, 2016.

Maghfuroh, Kholifatul. Wawancara, Babat, 20 November 2019.

SMP N2 Babat Lamongan. Observasi, Babat, 20 November 2019.

Depdiknas. Undang-Undang No. 20 Tahun 2003:Tentang Sistem Pendidikan Nasional Jakarta: t.p., 2003. 